\title{
Short communication: Performance of lactating dairy cows fed pearl millet grain
}

\author{
A. F. Mustafa ${ }^{1}$ \\ Department of Animal Science, Macdonald Campus, McGill University, Sainte-Anne-De-Bellevue, Quebec, H9X 3V9, Canada
}

\begin{abstract}
Fifteen multiparous Holstein cows were used in a $3 \times$ 3 Latin square experiment to determine the effects of feeding pearl millet grain on feed intake, milk yield, and milk composition of lactating dairy cows. Three isonitrogenous diets with a 57:43 forage:concentrate ratio were formulated. Diets contained $30 \%$ corn, $30 \%$ pearl millet, or $31 \%$ corn and pearl millet mixed 1:1 (wt/ wt). Three lactating Holstein cows fitted with ruminal cannulas were used to determine the effects of dietary treatments on ruminal fermentation parameters. Dry matter intake and energy-corrected milk were similar for all dietary treatments and averaged 23.8 and 33.5 $\mathrm{kg} / \mathrm{d}$, respectively. Dry matter intake (\% of BW) was unaffected by dietary treatments and averaged $3.40 \%$. Milk fat, protein, lactose, and total solids concentrations were not influenced by grain type. Ruminal $\mathrm{NH}_{3}-$ $\mathrm{N}$ concentration was unaffected by dietary treatments. However, ruminal $\mathrm{pH}$ tended to be lower for cows fed pearl millet than those fed corn and pearl millet mix. It was concluded that pearl millet grain can replace corn in dairy cow diets up to $30 \%$ of the diet DM with no adverse effects on milk yield or milk composition.
\end{abstract}

Key words: milk yield, milk composition, pearl millet grain

Pearl millet [Pennisetum glaucum (L.) R.] is a tropical plant processing the $\mathrm{C} 4$ photosynthetic pathway (Nelsen, 1995) with tolerance to drought, heat, and low soil $\mathrm{pH}$. Because of its adaptability to harsh conditions, millet can be grown in areas unfavorable to other cereals such as corn (Hanna, 1995). Pearl millet is also grown as a summer grain crop to replace sorghum in areas with low water-holding soils and short growing seasons (Pale et al., 2003). Relative to corn, pearl millet contains greater concentrations of $\mathrm{CP}$ but less starch (Nocek and Tamminga, 1991; Hill et al., 1996). Ruminal degradability of pearl millet is greater than that of corn but less than that of barley and oats (Nocek and

Received June 10, 2009.

Accepted October 30, 2009.

${ }^{1}$ Corresponding author: arif.mustafa@mcgill.ca
Tamminga, 1991). Pearl millet has successfully replaced corn in diets of broilers (Collins et al., 1997), beef cattle (Hill et al., 1996), and lactating goats (Gelaye et al., 1997). However, the nutritive value of pearl millet for lactating cows has not been investigated. Adapted and high-yielding hybrids of pearl millet suitable for growing conditions in eastern Canada have recently been developed by Agriculture and Environmental Renewal Canada (Delhi, Ontario, Canada). The new hybrids produce 3 to $3.5 \mathrm{Mg} /$ ha of grain under nonirrigated and drought conditions and also suppress root-lesion nematodes when used in crop rotation (AERC, 2005; Bélair et al., 2005). Nutrient profile and ruminal nutrient degradabilities of these hybrids have already been determined (Mustafa et al., 2008). However, their feeding value for ruminants has not been evaluated. The objectives of this study were to determine the effects of replacing corn with pearl millet in the diets of lactating dairy cows on subsequent milk yield and composition and on ruminal fermentation.

All experimental procedures were preapproved by the Faculty Animal Care Committee at McGill University (Sainte-Anne-de-Bellevue, Quebec, Canada). Fifteen multiparous cows $(\mathrm{DIM}=76 \pm 24 \mathrm{~d}, \mathrm{BW}=704 \pm$ $76.9 \mathrm{~kg}$ ), including 3 ruminally fistulated cows, were used in a $3 \times 3$ Latin square experiment with 24 -d periods. Three isonitrogenous diets were formulated with a 57:43 forage:concentrate ratio. Corn in the first $\operatorname{diet}(30 \%$ of the diet DM) was replaced by 50 and $100 \%$ (wt/wt) of CGPMH 90 pearl millet in diets 2 and 3, respectively (Table 1). Diets were offered ad libitum as TMR twice daily at 0800 and $1600 \mathrm{~h}$. Experimental periods consisted of $14 \mathrm{~d}$ of diet adaptation and $14 \mathrm{~d}$ of data collection. Feed intake and milk yield were measured on d 15 to 28 of each period. Cows were milked twice daily and milk samples were pooled by proportion according to milk yield at each milking. Diets and grains were sampled daily during each collection period and composited by period.

The composited feed samples were oven-dried at $60^{\circ} \mathrm{C}$ for $48 \mathrm{~h}$, ground through a 1-mm screen, and stored for later analysis. Orts were measured daily to determine daily feed intake for each cow. Ground feed and grain samples were analyzed for DM, ash, and ether extract 
Table 1. Ingredients and chemical composition of dietary treatments (DM basis)

\begin{tabular}{|c|c|c|c|}
\hline \multirow[b]{2}{*}{ Item } & \multicolumn{3}{|c|}{ Dietary treatment } \\
\hline & Corn & Corn plus pearl millet & Pearl millet \\
\hline \multicolumn{4}{|l|}{ Ingredient, \% } \\
\hline Alfalfa silage & 30.0 & 29.7 & 31.0 \\
\hline Corn silage & 17.3 & 17.3 & 17.3 \\
\hline Grass hay & 6.9 & 6.9 & 6.9 \\
\hline Ground corn & 30.2 & 15.8 & \\
\hline Ground millet & & 15.4 & 30.2 \\
\hline Soybean meal & 8.8 & 8.0 & 7.4 \\
\hline AminoPlus $^{1}$ & 3.5 & 3.5 & 3.5 \\
\hline Megalac $^{2}$ & 1.5 & 1.5 & 1.5 \\
\hline Sodium bicarbonate & 0.9 & 0.9 & 0.9 \\
\hline Blue salt ${ }^{3}$ & 0.4 & 0.4 & 0.4 \\
\hline Mineral $\operatorname{mix}^{4}$ & 0.6 & 0.6 & 0.6 \\
\hline \multicolumn{4}{|c|}{ Chemical composition, \% } \\
\hline $\mathrm{DM}$ & 50.4 & 49.8 & 50.0 \\
\hline Ash & 6.2 & 6.4 & 6.3 \\
\hline Ether extract & 3.3 & 3.7 & 4.0 \\
\hline $\mathrm{CP}$ & 17.0 & 17.5 & 17.7 \\
\hline $\mathrm{NDF}$ & 36.3 & 38.9 & 40.0 \\
\hline $\mathrm{ADF}$ & 24.0 & 24.2 & 23.3 \\
\hline $\mathrm{Ca}$ & 0.73 & 0.71 & 0.82 \\
\hline $\mathrm{P}$ & 0.39 & 0.39 & 0.40 \\
\hline \multirow{2}{*}{\multicolumn{4}{|c|}{$\begin{array}{l}{ }^{1} \text { Contained } 50.5 \% \mathrm{CP}, 20 \% \mathrm{NDF}, 8 \% \mathrm{ADF}, 1.4 \% \text { ether extract, } 0.42 \% \mathrm{Ca} \text {, and } 0.7 \% \mathrm{P} . \mathrm{Ag} \text { Processing Inc } \\
\text { (Omaha, NE). }\end{array}$}} \\
\hline & & & \\
\hline \multicolumn{4}{|c|}{${ }^{2}$ Church and Dwight (Princeton, NJ). } \\
\hline \multicolumn{4}{|c|}{${ }^{3}$ Contained $99 \% \mathrm{NaCl}, 400 \mathrm{mg} / \mathrm{kg}$ of $\mathrm{Co}$, and $70 \mathrm{mg} / \mathrm{kg}$ of I. } \\
\hline \multicolumn{4}{|c|}{$\begin{array}{l}{ }^{4} \text { Contained per } \mathrm{kg}: 4.5 \% \mathrm{Ca}, 2.5 \% \mathrm{P}, 6.6 \% \mathrm{Na}, 1.5 \% \mathrm{Mg}, 1.2 \% \mathrm{~K}, 0.11 \% \mathrm{~S}, 1,372 \mathrm{mg} \text { of } \mathrm{Fe}, 1,032 \mathrm{mg} \text { of } \mathrm{Mn} \text {, } \\
1,500 \mathrm{mg} \text { of } \mathrm{Zn}, 247 \mathrm{mg} \text { of } \mathrm{Cu}, 16 \mathrm{mg} \text { of I, } 16 \mathrm{mg} \text { of Co, } 10 \mathrm{mg} \text { of Se, } 185,000 \mathrm{IU} \text { of vitamin A, 32,500 IU of } \\
\text { vitamin } \mathrm{D}_{3} \text {, and } 900 \mathrm{IU} \text { of vitamin E. }\end{array}$} \\
\hline
\end{tabular}

using standard procedures (AOAC, 1990). Neutral detergent fiber (Van Soest et al., 1991) and ADF (AOAC, 1990) were determined using an Ankom fiber analyzer (Ankom Inc., Fairport, NY). The NDF analysis was conducted using $\alpha$-amylase and without the use of sodium sulfite. Crude protein was measured with a Leco nitrogen analyzer (FP-428 Nitrogen Determinator, Leco Corporation, St. Joseph, MI). Grains were also analyzed for starch content according to McCleary et al. (1997). Milk samples were analyzed for fat, protein, lactose, and MUN by using an infrared analyzer (MilkoScan model Foss 4000, Foss Food Technology, Hillerød, Denmark). Milk TS were determined according to AOAC (1990).

Three multiparous, lactating Holstein cows fitted with rumen cannulas were used to determine the effects of the dietary treatments on ruminal fermentation parameters. Periods consisted of $14 \mathrm{~d}$ of diet adaptation and $7 \mathrm{~d}$ of data collection. Dietary treatments were the same as in the production study. Samples of ruminal fluid were collected from various part of the rumen at $0,2,4,6,8,10$, and $12 \mathrm{~h}$ post morning feeding as described by Vargas-Bello-Pérez et al. (2008). Ruminal $\mathrm{pH}$ was measured immediately using an Accumet $\mathrm{pH}$ meter (AB15 Plus, Fisher, Pittsburgh, PA). Ten milliliters of ruminal fluid was preserved by adding $1 \mathrm{~mL}$ of $0.1 \mathrm{~N} \mathrm{HCl}$ and was later analyzed for $\mathrm{NH}_{3}-\mathrm{N}$ colorimetrically with a multichannel Lachat Autoanalyzer (Lachat Instruments, Milwaukee, WI).

Data for the production study were analyzed as a $3 \times$ 3 replicated Latin square design using PROC MIXED of SAS (SAS Institute, 1989) with fixed effects of treatment and period, and cow within period as the random effect. Data for ruminal parameters were analyzed as repeated measurements across time by using PROC MIXED of SAS. The model included effects of treatment, period, time, and treatment by time interaction. Significant differences were declared at $P<0.05$.

Pearl millet used in this study contained (mean \pm SD) $2.0 \pm 0.09 \%$ ash, $6.7 \pm 0.14 \%$ ether extract, 13.9 $\pm 0.70 \% \mathrm{CP}, 63.4 \pm 1.82 \%$ starch, $18.3 \pm 0.68 \% \mathrm{NDF}$, and $4.4 \pm 0.57 \% \mathrm{ADF}$. Respective values for corn were $1.3 \pm 0.3,3.9 \pm 0.53,9.1 \pm 0.26,72.2 \pm 1.46,15.3 \pm$ 1.34 , and $8.2 \pm 0.76 \%$. The chemical profile of pearl millet in this study was within the range previously reported for 5 different hybrids grown in southwestern Quebec (Mustafa et al., 2008).

Intakes of DM $(P=0.786)$ and $\mathrm{CP}(P=0.216)$ were not affected by dietary treatments; however, cows fed pearl millet consumed more $(P=0.010)$ NDF than those fed corn (Table 2). This was likely because of the higher NDF content of pearl millet relative to corn. 
Table 2. Effects of feeding pearl millet grain on performance of dairy cows

\begin{tabular}{|c|c|c|c|c|c|}
\hline \multirow[b]{2}{*}{ Item } & \multicolumn{3}{|c|}{ Dietary treatment } & \multirow[b]{2}{*}{$\mathrm{SEM}^{1}$} & \multirow[b]{2}{*}{$P$-value ${ }^{2}$} \\
\hline & Corn & Corn plus millet & Pearl millet & & \\
\hline \multicolumn{6}{|l|}{ Intake, $\mathrm{kg} / \mathrm{d}$} \\
\hline $\mathrm{DM}$ & 23.7 & 24.1 & 23.5 & 0.51 & 0.786 \\
\hline $\mathrm{CP}$ & 4.0 & 4.2 & 4.2 & 0.09 & 0.216 \\
\hline $\mathrm{NDF}$ & $8.6^{\mathrm{b}}$ & $9.4^{\mathrm{ab}}$ & $9.5^{\mathrm{a}}$ & 0.20 & 0.032 \\
\hline Intake, $\%$ of BW & 3.33 & 3.45 & 3.41 & 0.114 & 0.730 \\
\hline \multicolumn{6}{|l|}{ Milk, kg/d } \\
\hline Yield & 39.6 & 40.0 & 39.9 & 2.18 & 0.990 \\
\hline $\mathrm{ECM}^{3}$ & 33.8 & 33.7 & 33.1 & 1.78 & 0.978 \\
\hline Fat & 1.60 & 1.57 & 1.52 & 0.098 & 0.860 \\
\hline Protein & 1.23 & 1.22 & 1.21 & 0.053 & 0.988 \\
\hline Lactose & 1.81 & 1.81 & 1.79 & 0.106 & 0.491 \\
\hline TS & 4.66 & 4.69 & 4.66 & 0.242 & 0.966 \\
\hline SNF & 3.07 & 3.12 & 3.14 & 0.175 & 0.944 \\
\hline \multicolumn{6}{|l|}{ Composition, \% } \\
\hline Fat & 4.07 & 4.00 & 3.83 & 0.142 & 0.524 \\
\hline Protein & 3.13 & 3.09 & 3.07 & 0.063 & 0.794 \\
\hline Lactose & 4.56 & 4.52 & 4.48 & 0.047 & 0.491 \\
\hline TS & 11.85 & 11.77 & 11.76 & 0.183 & 0.921 \\
\hline SNF & 7.78 & 7.84 & 7.92 & 0.190 & 0.866 \\
\hline MUN, mg/dL & 13.6 & 14.6 & 13.9 & 0.60 & 0.209 \\
\hline Ruminal pH & 6.33 & 6.37 & 6.27 & 0.056 & 0.165 \\
\hline Ruminal $\mathrm{NH}_{3}-\mathrm{N}, \mathrm{mg} / \mathrm{dL}$ & 16.9 & 16.0 & 15.7 & 3.26 & 0.923 \\
\hline
\end{tabular}

Grain type had no effect on milk yield $(P=0.990)$ and ECM $(P=0.978)$, which averaged 39.8 and $33.5 \mathrm{~kg} / \mathrm{d}$, respectively. Yields of milk fat $(P=0.860)$, protein $(P$ $=0.988)$, and lactose $(P=0.491)$ were also unaffected by grain type. No data on lactational performance of dairy cows fed pearl millet are available. However, replacing corn with pearl millet in diets of lactating goats (up to $40 \%$ of diet DM) had no effect on feed intake or milk yield (Gelaye et al., 1997). Inclusion of pearl millet in beef cattle diets resulted in performance similar to that obtained with corn and sorghum (Hill and Hanna, 1990; Hill et al., 1996). It has been reported that in ruminant diets with similar CP concentrations, pearl millet can supply between 85 and $92 \%$ of the energy found in corn (Hill et al., 1996; Gelaye et al., 1997). However, ME intake was similar when the grains were fed at $40 \%$ of the dietary DM (Terrill et al., 1998). Milk fat $(P=0.524)$, protein $(P=0.794)$, lactose $(P=$ $0.491)$, total solids $(P=0.921)$, SNF $(P=0.866)$, and MUN $(P=0.209)$ concentrations were also unaffected by grain type. Similar findings have also been observed when pearl millet replaced corn in the diets of dairy goats (Gelaye et al., 1997).

No time by treatment interactions were noted for ruminal fermentation parameters and therefore only main effects were reported in Table 2. Grain type had no effect on ruminal $\mathrm{pH}(P=0.165)$ or $\mathrm{NH}_{3}-\mathrm{N}$ concen- tration $(P=0.923)$. However, a tendency $(P=0.074)$ for a higher ruminal $\mathrm{pH}$ was observed for cows fed the corn-millet mix relative to those fed the pearl millet. Replacing corn with pearl millet in diets of beef cattle increased ruminal $\mathrm{pH}$ in one study (Hill et al., 1996) and decreased it in another (Hill and Hanna, 1990). In growing goats, substituting pearl millet for corn had no influence on ruminal $\mathrm{pH}$ but depressed $\mathrm{NH}_{3}-\mathrm{N}$ concentration. Reasons for discrepancies in ruminal fermentation parameters between studies may include grain inclusion level, forage:concentrate ratio, and differences among animal species.

In conclusion, pearl millet can be used to replace corn up to $30 \%$ of the diet DM in the diets of lactating dairy cows with no adverse effects on milk yield or milk composition. Feeding pearl millet to lactating dairy cows may reduce supplemental protein traditionally added to corn-based diets. Further studies are needed to determine the effects of long-term feeding of pearl millet grain on performance of dairy cows. The feeding of pearl millet grain with different forage:concentrate ratios warrants further investigation.

\section{REFERENCES}

Agriculture Environmental Renewal Canada. 2005. Canadian grain pearl millet. http://www.aerc.ca/grainpearl.html Accessed Aug. 20, 2005. 
AOAC. 1990. Official Methods of Analysis. 15th ed. Vol. 1. Assoc. Off. Anal. Chem., Arlington, VA.

Bélair, G., N. Dauphinais, Y. Fournier, O. P. Dangi, and M. F. Clément. 2005. Effect of forage and grain pearl millet on Pratylenchus penetrans and potato yields in Quebec. J. Nematol. 37:78-82.

Collins, V. P., A. H. Cantor, A. J. Pescatore, M. L. Straw, and M. J. Ford. 1997. Pearl millet in layer diets enhances egg yolk n-3 fatty acids. Poult. Sci. 76:326-330.

Gelaye, S., T. Terrill, E. A. Amoah, S. Miller, R. N. Gates, and W W. Hanna. 1997. Nutritional value of pearl millet for lactating and growing goats. J. Anim. Sci. 75:1409-1414.

Hanna, W. W. 1995. Breeding pearl millet for grain production. Pages 8-12 in Proc. Natl. Grain Pearl Millet Symp., Tifton, GA. University of Georgia, Tifton.

Hill, G. M., and W. W. Hanna. 1990. Nutritive characteristics of pearl millet grain in beef cattle diets. J. Anim. Sci. 68:2061-2066.

Hill, G. M., G. L. Newton, M. N. Streeter, W. W. Hanna, P. R. Utley, and M. J. Mathis. 1996. Digestibility and utilization of pearl millet diets fed to finishing beef cattle. J. Anim. Sci. 74:1728-1735.

McCleary, B. V., C. C. Gibson, and C. C. Mugford. 1997. Measurements of total starch in cereal products by amyloglucosidase $\alpha$-amylase method. Collaborative study. J. AOAC Int. 80:571-579.

Mustafa, A. F., P. Seguin, G. Belair, and A. Kumar. 2008. Chemical composition and ruminal degradability of grain pearl millet grown in southwestern Quebec. Can. J. Anim. Sci. 88:71-77.
Nelsen, C. J. 1995. Photosynthesis and carbon metabolism. Pages 3141 in Forages. F. Barnes, D. A. Miller, and C. J. Nelsen, ed. Iowa State University Press, Ames.

Nocek, J. E., and S. Tamminga. 1991. Site of digestion of starch in the gastrointestinal tract of dairy cows and its effect on milk yield and composition. J. Dairy Sci. 74:3598-3629.

Pale, S., S. C. Mason, and T. D. Galusha. 2003. Planting time for early-season pearl millet and grain sorghum in Nebraska. Agron. J. 95:1047-1053.

SAS Institute. 1989. SAS/STAT User's Guide: Statistics. SAS Inst. Inc., Cary, NC.

Terrill, T. H., S. Gelaye, E. A. Amoah, S. Miller, B. Kouakou, R. N. Gates, and W. W. Hanna. 1998. Protein and energy value of pearl millet for lactating and growing goats. J. Anim. Sci. 76:19641969.

Tyrrell, H. F., and J. T. Reid. 1965. Prediction of the energy value of cow's milk. J. Dairy Sci. 48:1215-1233.

Van Soest, P. J., P. J. Robertson, and B. A. Lewis. 1991. Methods for dietary fiber, neutral detergent fiber, and nonstarch polysaccharides in relation to animal nutrition. J. Dairy Sci. 74:3583-3597.

Vargas-Bello-Pérez, E., A. F. Mustafa, and P. Seguin. 2008. Effects of feeding forage soybean silage on milk production, nutrient digestion, and ruminal fermentation of lactating cows. J. Dairy Sci. 91:229-235. 